\title{
The Impacts of Outward Foreign Direct Investment on Home Firm's Productivity: A Study of Chinese Multinationals
}

\author{
Chewei Teng ${ }^{1}$, Hsu Wen Chung ${ }^{2}$, Huang Jin Wei ${ }^{2}$, Ho Wen Cheng ${ }^{2}$, Tsai Cheng Tao ${ }^{2, *}$ \\ ${ }^{1}$ School of Public Affairs, University of Science \&Technology of China, China \\ ${ }^{2}$ Department of International Business Studies, National Chi Nan University, Taiwan
}

Received September 24, 2019; Revised October 28, 2019; Accepted November 10, 2019

Copyright $\subseteq 2019$ by authors, all rights reserved. Authors agree that this article remains permanently open access under the terms of the Creative Commons Attribution License 4.0 International License

\begin{abstract}
This paper examines the impacts of outward foreign direct investment (OFDI) on the home firm's productivity in an emerging economy. Based on the literature review and findings from this paper of Chinese outward investing firms, we develop a conceptual framework that integrates the resource-based view, industrial organization economics, and institutional view of international business study. In our findings, they show that the integrating model of three aspects have higher explanation than the individual aspect model. We use firm-level data to explain how the firm-specific factors, industrial factors, and national institution factors affect productivity in Chinese OFDI firms. Also, this analysis of firm-level data can provide evidences in the effectiveness of resource using, competitiveness, and policy impact on individual firms.
\end{abstract}

Keywords Outward Foreign Direct Investment, Home Country Productivity

\section{Introduction}

The phenomenal growth of China's outward foreign direct investment (ODFI) provides both challenges and opportunities to researchers (Cui, Jiang, 2010). While there are many studies, have explored the China's outward FDI and relationship between home country productivity (Haskel et al., 2002). The home country productivity effect of OFDI has acknowledged still scant concentration in the empirical literature (Hsu et al., 2011). Due to the uneven distribution of resources, a domestic firm might seek the set of advantages for better development in a foreign country (Dunning, 2000). Lieberman \& Kang (2008) argue that one such comprehensive indicator of the firm's performance is productivity.

What is an important determinant of productivity growth at the firm level? It is often assumed that FDI brings benefits to host country economics through productivity spillovers from multinational enterprises (Nigel \& James, 2007). From the host country's perspective, the primary expected economic benefit, on the contrary, it is interesting to see how home country firms focus on the domestic market, and that special features of OFDI how affect domestic firm's productivity. As an indicator of efficiency, productivity should be affected by the trade between the two countries. Investigating the earlier researchers used the method of econometrics to prove that the relationship between home country productivity and international trade must have been significantly positive or negative (Montagna, 2001; Melitz, 2003). In addition, Head \& Ries (2003) and Eaton et al. (2004) observed that, the more numbers of OFDI countries a firm invested, the higher performance in productivity. We can concern that firms go offshore owing to attaining firm-specific ownership against liabilities of foreignness (Dunning, 1993).

According to previous findings of productivity and ODFI, this study argues a number of common approaches to productivity upon FDI, and regard the productivity determinants concluded some FDI factors such as the amounts of OFDI, and the regions of investment. Specifically, the research question is to examine the role of firm-level characteristics as well as outward foreign direct investment for home country productivity activity.

On the other hand, unlike the main research focused on developed countries, what are the significant factors that impact the relationship between China's OFDI and home country firm's productivity? We still understand less about the heterogeneity that may exist in these productivity effects of OFDI across industries in emerging 
markets (Hsu et al., 2011). To approach this important question, so we need to consider existing literature while taking into consideration the special features of Chinese OFDI and home country productivity effect.

This study aims to make contributions to the literature in three points. First, to figure out the home country productivity effect of OFDI, which occur in emerging economies in order to fill out the research gaps that there are few literatures on OFDI impacts that influence productivity. Second, with empirical evidences, this study developed that there are still other factors of OFDI such as firm competencies, industrial competition, and national institution (Wang et al., 2012) and try to put some indicators which represent these factors into this study's model in order to determine whether these factors can also be used in productivity analysis or not. Third, attempt to offer some information for the firm in the emerging economies from this empirical research. The results may help the firm to make strategies on OFDI to increase productivity at home.

\section{Theoretical Background and Hypotheses}

\subsection{Impact on Productivity}

Theoretical work has generally predicted positive effects of FDI on domestic firms' productivity through the labor mobility channel (Kaufmann, 1997; Fosfuri et al., 2001) or through competition and demonstration effects (Wang \& Blomstrom, 1992). These models predicted home country productivity by FDI inflows. That can be regarded as there was a knowledge spillover effect on host countries. Technology transfers to host countries from home countries (Xu, 2000). Wei. Zhao et al. (2010) found that China's increased foreign presence in developed countries was associated with productivity effects at home. Zhou et al. (2002) show that FDI may exert a different impact on firms at the regional level than it does on firms at the industrial scale in China.

Furthermore, OFDI is argued that there have positive effects on productivity. However, in the finding of Bitzer \& Görg (2005), they found that firms locating aboard are able to advance in their performance at home as they become exposed to international competition and best practice. Also, Driffield et al. (2009) proved that the firm would search for skill employed by OFDI, lack of organizational skills and industry knowledge, the overseas operations of firms from a laggard country tend to be short term- oriented and less sophisticated (Buckley et al., 2002). They use FDI outflows to develop a prediction on productivity. From their results, they must have to focus attention on through that FDI outflows can represent the degrees of OFDI. The FDI outflows can be regarded as an aggregation of the amount of capital invested in foreign areas of all firms. In a firm-level analysis, to consider taking the amount of capital invested in foreign areas as FDI outflows of one firm.

Dunning (1993) provides a holistic approach to explain FDI activities. It provides additionally detailed that firms FDI activity is determined by ownership, location, and internationalization activity. Johanson \& Vahlne (1977) observed outward investment as a learning process for the home country MNEs. Stage model highlights the importance of the gradual acquisition of international knowledge. Firm-specific advantage is usually intangible, and if a foreign firm is to be successful in another country, it must have some kind of a benefit that vanquishes the costs of operating in an abroad market (Dunning, 2000). Dunning's eclectic paradigm (2000) explains that location was the key factor to affect the performance of a foreign investment. The mainstream theory of location refers to the firms need to use jointly with their competitive advantages, favor a presence in a foreign location, the more firms will choose to augment or exploit their specific advantages by engaging in FDI (Dunning, 2000). Much research (Andersson \& Fredriksson, 1996; Wei, \& Liu, 2006) included location dummy as they define how characteristics of a region can influence the productivity. The firm's investment strategy through FDI in developing countries is especially important because most of the home-country firm's productivity effect related with a location choice.

Additionally, in the manufacturing industry, research has linked productivity levels to several features of technology, demand, and market structure. Examples include the effect of $R \& D$ and productivity growth (Cuneo \& Mairesse, 1983); intangible assets (Denekamp, 1995); perfect competition (Roeger, 1985); R\&D, exports (Wei \& Liu, 2006). Given the large differences in productivity within a manufacturing industry that this study discussed above, the normal question is to ask how the OFDI affecting productivity is via choosing investing area and industry. So this study emphasized whether firms in the manufacturing industry would increase higher productivity. Most of the products are solid in the manufacturing industry; we can examine the productivity by visible sales-to employee ratio. Other industries, such as Internet services, banks, and transportation service, are hard to define productivity. That may not have a positive relationship significantly with productivity, and we must draw attention to setting a manufacturing industry dummy in the present study's models.

In our hypotheses, Manufacturing factor and Location factors are moderators of OFDI, which influence labor productivity. We would like to prove how the OFDI affecting productivity is via choosing investing area and industry selecting. In summary, we, therefore, develop the following hypothesis:

Hypothesis 1: The productivity of home countries undertaken by Chinese OFDI firms is positively related to 
its amount of capital invested in foreign areas.

(a) The intensity of OFDI involvement will be moderated by location and manufacturing industry factors.

(b) While the productivity of Chinese OFDI firms is positively or negatively related its amount of capital invested in different specific foreign areas?

(c) While the productivity of Chinese OFDI firm is negatively related to manufacturing OFDI firms.

\subsection{Resource-Based View of the Firm}

RBV provides a theory that a firm operated in an oversea market to gain comparative advantages by exploring and exploiting valuable resources like technological capabilities, brand-names, and scientific knowledge, which are making a firm raise up the quantities of output. Then, the consequence of comparative advantages can be measured in productivity (Mahoney \& Pandain, 1992). The RBV is companionable with the typical conceptualization of international expansion (Dunning, 1993). To sum up, we can call attention to link the RBV with productivity and rationally make hypotheses that there is a relationship between them in FDI activities.

When it comes to the resource-based views, human capital is a sort of firm-specific resource which is discussed by numerous researches (e.g., Wright et al., 1991; Datta et al., 2005). Wright et al. (1991) defined human resources as the pool of human capital under the firm's control in a direct employment relationship. Dunning (1998) maintains that the skill and education level of labor can influence both the volume of FDI inflows and Root \& Ahmed (1979) found that none of the variables they use as proxies for human capital and skilled labor is a significant determinant of FDI for the 58 developing countries considered. Increasing the skill level of the domestic firm's workforce will also increase the ease and efficiency with which new technologies are introduced into the workplace.

Human resource practices, on the other hand, may that various features of the within-firm distribution of human capital differentiate firms and are relate to the firm's productivity and the organizational activities directed at managing the pool of human capital and ensuring that the capital is employed toward the fulfillment of organizational goals. This leads to recognizing two aspects of human capital. There are many features of human capital like gender, age, education, the duration of training period, etc. In the research of Black \& Lynch (1996), they used the education quality of employees to measure the effects on productivity.

In the same way, we expect that Chinese firms with strong human capital are most likely to increase to productivity.

There is one further factor that we must not ignore. The capability of making costs down during operation is another firm-specific advantage. Some of the researches are linked to cost advantage with productivity, such as process-focused practices that increase efficiency and productivity and reduce inputs and wastes (e.g., Christmann, 2000; Hart, 1995; Klassen \& Whybark, 1999). Significant cost savings relative to competitors; these savings result from avoiding the cost of installing and operating end-of-pipe- pollution control devices, increased productivity and efficiency, reduced costs of implementing regulations, and reduced legal liabilities (Sharma \& Vredenburg, 1998). Consequently, Operating cost is negatively related to firms' productivity because firms exploit their cost-down capability to increase productivity. From the reasons above, we bring together the following hypothesis:

Hypothesis 2: The productivity of home countries undertaken by Chinese OFDI firms is positively related to (a) its human resources, but negatively related to (b) its operating costs.

\subsection{Industrial Organization Economics}

From an industry-based view, traditional industrial organization theoretical emphasizes that performance relies on the conditions within a given industry (Porter, 1990). The conditions conclude comparative rivalry, entry barrier, and threat of substitutes etc. These constraint conditions may shape a comparative circumstance in an industry (Bartelsman et al., 2002). The firms which overcome these constraints can survive in the industry and achieve positional advantages. Yet, differences in productivity may also be the result of structural differences, i.e., differences in the composition of output within a particular industry or sector (Pilat, 1996). The level of competition in an industry may also influence the productivity of a firm. Through intense competition in the industry, the performance of firms is improving, which is shown on the increasing productivity (Nickel, 1996).In addition, the firm may chase international development to find new cost-effective opportunities if the level of competition within an industry is high. Overall, we can conclude that the heterogeneous character of the industry, such as the component of industries, the level of competition, and the routine of building management structures, make effects on the productivity of a firm.

Transformation in key factors, like government control and degree of openness to foreign investors, affected the industrial environment (Wang et al., 2009). The literature on industrial organization lay emphasis on the role of a firm's competitive environment. From prior researches, we have observed the competitive intensity, which influenced market share and bargaining power, from the number of firms in the industry (e.g., Sjöhölm, 1998; Zhang et al., 2001). A higher degree in competition in an industry can make higher productivity for a firm (Nickel, 1996). 
Market share is one of the factors that literature on industry organization concerned with. Aw et al. (2000) find evidence that firms with higher productivity levels relative to the incumbent average exit after the exposure to trade. It is obvious that by reallocating market shares from less productive firms who exit to more productive ones who export and therefore contribute to industry productivity growth (Melitz, 2003). From their researches suggest that if a firm wants to grow in productivity, it has to develop foreign market activities in order to getting more share of the market. Thus, we may consider including market share to be a factor of productivity. This discussion leads to our hypothesis:

Hypothesis 3: The productivity of home countries undertaken by Chinese OFDI firms is positively related to (a) degree of competition; (b) it's market shares within the industry;

\subsection{Institutional Theory}

According to the institutional-based view, the national policy decides the rule of allocation of resources and the procedure of industry development. Thus, productivity can be boosted by national force. For example, in the research of Fleisher \& Chen's observation (1997), because of the difference in regional development policy, the areas in China of coastal and non-coastal provinces' total factor productivity are diverse. Moreover, institutional theory can explain how a national force can boost productivity by policymaking (Scarpetta et al., 2002). Especially in mainland China, The economy was shaped by the Communist Party of China (CPC) through the full sessions of the Central Committee and national congresses. The party plays an important role in launching the foundations and principles of Chinese communism, planning strategies for economic development, setting growth targets, and beginning reforms. However, Policies and institutions may also have a role in shaping firm size (Scarpetta et al., 2002). Firms in China quiet feature an inheritance of governmental involvement in a business affair in spite of the development of the market system (Luo et al., 2010). Firms that get public support can grow in dramatically way. From the finding of Guellec \& Van Pottelsberghe de la Potterie (2004), they show several factors determine the extent to which each source of knowledge contributes to productivity growth. These factors are the socioeconomic objectives of government support and the type of public institutions that perform R\&D. Also, Government and university R\&D has a direct effect on scientific, basic knowledge and on public missions.

On the one hand, CPC develops five-year plans beginning from 1953 every five years. It provides the top guide strategies in developing industries and policymaking during the period. Since the 2000s, the "going out" policy has been applied. Therefore, OFDI firms that are benefited by the policy at that time can boost their productivity by government support. On the other hand, compare to non-state firms, Chinese state-owned firms have sturdy political capability that in order to help get contact with tactically essential factor resource that the state controls (Warner et al., 2004). Also, as the market for crucial inputs remains unfledged in China, state ownership is regularly linked with significant political and economic benefits and superior public endowment that can broaden the scope of their resource base and assist firm with high state ownership invest aboard (Wang et al., 2012).

In contrast, this study highlighted that the degree of Chinese economic reform policy of opening up foreign ownership of firms which influences productivity. Earlier studies in inward foreign direct investment (IFDI) impact productivity tell us that a firm in domestic market can be benefitting from foreign presences (e.g., Caves, 1974; Liu et al., 2000; Sun, 2012). Domestic firms in counties that appeal more FDI or have a long history of FDI tend to have higher productivity, while domestic firms in industries that have more FDI or have a long history of FDI tend to have lower productivity (Zhou et al., 2002). Many studies claimed that technology transfer and spillover of knowledge caused the increasing productivity in host countries (Johanson, J., \& Vahlne, J. E. 1977; Xu, B. 2000; Buckley et al., 2002). However, there is some evidence that can tell us IFDI is one of the factors that can affect productivity in countries. We can determine the effect of IFDI impact by telling the ratio of foreign ownership in the firm. Also, McGuckin and Nguyen (1995) suggest that ownership change is generally associated with the transfer of plants with above-average productivity. Based on the discussion above, we develop the following hypothesis:

Hypothesis 4: The productivity of home countries undertaken by Chinese OFDI firms is positively related to (a) whether it is supported by five-year plans of government policy; (b) the level of state ownership in the firm concerned; (d) the level of foreign ownership in the firm concerned.

\section{Data and Methods}

In order to examine our hypotheses and assess the productivity determinants of Chinese OFDI firms, we take some statistical datasets such as Statistical Bulletin of China's Outward Foreign Direct Investment and China Industry Economy Statistical Yearbook to acquire the industrial panel data for 1999 to 2010. These were obtained from the State Statistical Bureau of China. Take the method of classifying the industries in China. They divided industries into twenty-five, and these two statistical datasets reveal the number of firms in the industry, value of output in the industry. We can get 
calculate the level of industrial competition and market shares from the data. Also, they can determine whether the firm is in the manufacturing industry or not.

The most important, our firm-level data is collected from the Taiwan Economic Journal. This database provides firm-level data from China. It reveals listed firms in Shanghai and Shenzhen stock exchanges. It contains the income statements and financial position statements of firms that could tell the performance of productivity and other variables. To serve the objective of the study, there are incomplete data in TEJ. In order to fill the missing data which is not revealed in TEJ, we take the information on China Securities Journal, which is hosted by Xinhua News Agency. We combine two datasets to make our setting more comprehensive. Finally, we deleted the incomplete FDI data in our database, but they are still unbalanced panel data. However, attrition is likely to be random due to imperfect reporting, rather than exit of firms. We collected 237 firms from 1999 to 2010, which is the period "going-out" policy applied. There are 1163 observations in our datasets to show investment cases in overseas.

\subsection{Dependent Variable}

\subsubsection{Labour Productivity}

In line with the objective of the study, the dependent variable of the model is labor productivity. T Following several other studies, like Caves (1974), Liu et al. (2000), and Hsu et al. (2011), labor productivity has measured as a sales-to-employee ratio. It is reasonable that this ratio represents the value of per staff creates. To put the matter, we take the annual sales to divide the number of employees of the firm from the dataset which we collected. Nevertheless, we define the productivity of LP into our equations.

\subsection{Independent Variables}

Our theoretical framework emphasizes FDI can be measured by two parts; one of measurement is OFDI. Likewise, OFDI in this analysis is operationalized as the actual amount of foreign direct investment of each firm. In the study of Wang et al. (2012), the same variable is accepted. Moreover, location is an important variable to FDI (Dunning, 1993). This study also set the investing areas as a dummy variable, where we divide into three regions. There are developed countries, emerging economies, and others. In this way, we can distinguish the feature of each foreign location. From our hypothesis 1, we consider putting manufacturing industry dummy because the productivity in the manufacturing industry is visible to measure. Finally, OFDI is the actual amount of foreign direct investment of each firm; DC means the OFDI is in developed countries; EE notes in emerging economies; OA records neither in developed countries nor in emerging economies. MD is the manufacturing industry dummy.

The empirical model also includes the firm-specific factors like human capital and operating cost. In the research of Black \& Lynch (1996), they used the education quality of employees to measure the effects on productivity. We take the number of employees who have a master's degree and bachelor's degree to divide total employees to see the ratio of higher education in the firm. What is more, in the researches of Christmann (2000), Hart (1995), and Klassen \& Whybark (1999), they denoted that operating cost is annual cost in operation of the firm. We take the same concepts to examine our models. However, HR denotes the ration of well-educated people in the firm. OPC is the annual operating costs of the firm.

Still, industrial organization economic indicates the factors which affect productivity. From prior researches, we can tell the competitive intensity, which influenced market share and bargaining power, from the number of firms in the industry (Zhang et al., 2001). Thus, this research takes the number of firms in the industry to signify the level of competition. On the other hand, we regard the ratio of annual sales of a firm to the values of industry created as market share indicator. From this discussion, we put NOF as the number of firms in the industry to represent the level of competition. MKS is a marker share that one firm posits.

Table 1. Measurement of Variables

\begin{tabular}{|c|c|}
\hline Variables & Measurement \\
\hline LP & Sales/employees \\
\hline OFDI & $\begin{array}{l}\text { The actual amount of foreign direct investment of } \\
\text { each firm }\end{array}$ \\
\hline DC & $\begin{array}{l}\text { Dummy variable of investing cases which in } \\
\text { developed countries }\end{array}$ \\
\hline $\mathrm{EE}$ & $\begin{array}{l}\text { Dummy variable of investing cases which in } \\
\text { emerging economies }\end{array}$ \\
\hline $\mathrm{OA}$ & $\begin{array}{l}\text { Dummy variable of investing cases which in other } \\
\text { areas }\end{array}$ \\
\hline MD & $\begin{array}{l}\begin{array}{l}\text { Manufacturing dummy, } \\
\text { other }=0\end{array} \\
\end{array}$ \\
\hline HR & $\begin{array}{l}\text { The number of employees who have the master and } \\
\text { bachelor degree/total employees }\end{array}$ \\
\hline OPC & Annual operating costs of the firm \\
\hline NOF & The number of firms in the industry \\
\hline MKS & Sales/Value of industry creates \\
\hline STD & State-planed dummy, national support $=1$, and none $=0$ \\
\hline DSO & $\begin{array}{l}\text { Dummy of state-owned shares of the firm, over the } \\
\text { average }=1 \text { and lower }=0\end{array}$ \\
\hline DFO & $\begin{array}{l}\text { Dummy of foreign-owned shares of the firm, } \\
\text { involved in foreign capitals }=1 \text { and none }=0\end{array}$ \\
\hline AGE & Firm age(year) \\
\hline SIZE & Firm size, the number of employees in a firm \\
\hline KL & Fixed capital employed/ employees \\
\hline
\end{tabular}

Lastly, this study's model includes three variables to 
account for the role of the institution. Firms can benefit by national support. We set state-planed dummy to denote that a firm is getting benefit from national support or not. Similarly, the ratio of the state share in the firm can be viewed as the control power of state ownership. From the previous studies, another measurement of FDI is IFDI. We follow studies such as $\mathrm{Li}$ (1998) and Benfratello \& Sembenelli (2006). We use the foreign-owned share of the firm to represent the IFDI effects. In our model, we set this variable into a dummy variable. If a firm includes foreign capitals, we set it 1 ; otherwise 0 . However, in our hypotheses, we are a focus on how IFDI impact as an "opening up" national policy. Conversely, we establish STD as a state-planned dummy and DSO as the ratio of state-owned share of the firm. If it is larger than the average $30.5747 \%$ in our data, we set 1 ; otherwise 0 ; we also set DFO to our equation to denote the ratio of the foreign-owned share of the firm, which is revealed by dummy-typed.

\subsection{Control Variables}

The previous approaches to test the impact of inward FDI on the productivity of host country productivity suggest that putting some control variables to the model (Caves, 1974; Liu et al., 2000; Hsu et al., 2011). Our model follows these researches to add some control variables like firm size and firm age. The firm size is denoted the number of employees. Next, the firm age is counted from the day the firm listed in the stock exchange. Likewise, as the preceding researches, we also set up an augmented Cobb-Douglas production function, which related labor productivity. However, we construct SIZE as firm size, AGE as firm age indicator, and $\mathrm{KL}$ as Cobb-Douglas production function.

\subsection{Developing Equations}

This study employed panel data regression (fixed effect model are employed according to Hausman test) to examine the variables. The advantage of using panel data is that it can effectively control heterogeneity among individuals. We develop equations by following the most previous studies (e.g., Zhou et al., 2002; Hsu et al., 2011). This study adopts a Cobb-Douglas production function to attain empirically results (showed as table 2).

In model 1, we test the FDI impacts on productivity and control variables. Model 1 is the baseline model of the study.
E1:

$$
\begin{array}{rl}
L P_{i t}=\alpha_{i}+\beta 1 & O F D I_{i t}+\beta 2 O F D I_{i t} * D C_{i t}+\beta 3 O F D I_{i t} \\
& * E E_{i t}+\beta 4 O F D I_{i t} * O A_{i t}+\beta 5 O F D I_{i t} \\
& * M D_{i t}+\beta 6 A G E_{i t}+\beta 7 S I Z E_{i t} \\
& +\beta 8 K L_{i t}+\varepsilon_{i t}
\end{array}
$$

Where $\mathrm{i}=1, \ldots \mathrm{n}$ (observations), $\mathrm{t}=1999, \ldots 2010$

In model 2, we add some factors to test the resource-based view on productivity.

E2:

$$
\begin{array}{rl}
L P_{i t}=\alpha_{i}+\beta 1 & O F D I_{i t}+\beta 2 O F D I_{i t} * D C_{i t}+\beta 30 F D I_{i t} \\
& * E E_{i t}+\beta 4 O F D I_{i t} * O A_{i t}+\beta 5 O F D I_{i t} \\
& * M D_{i t}+\beta 6 H R_{i t}+\beta 7 O P C_{i t} \\
& +\beta 8 A G E_{i t}+\beta 9 S I Z E_{i t}+\beta 10 K L_{i t} \\
& +\varepsilon_{i t}
\end{array}
$$

Where $\mathrm{i}=1, \ldots \mathrm{n}$ (observations), $\mathrm{t}=1999, \ldots 2010$

In model 3, industrial organization economic factors are included to test the effects on productivity.

$$
\begin{aligned}
& \text { E3: } \\
& \begin{array}{rl}
L P_{i t}=\alpha_{i}+\beta 1 & O F D I_{i t}+\beta 2 O F D I_{i t} * D C_{i t}+\beta 3 O F D I_{i t} \\
& * E E_{i t}+\beta 4 O F D I_{i t} * O A_{i t}+\beta 5 O F D I_{i t} \\
& * M D_{i t}+\beta 6 N O F_{i t}+\beta 7 M K S_{i t} \\
& +\beta 8 A G E_{i t}+\beta 9 S I Z E_{i t}+\beta 10 K L_{i t} \\
& +\varepsilon_{i t}
\end{array}
\end{aligned}
$$

Where $\mathrm{i}=1, \ldots \mathrm{n}$ (observations), $\mathrm{t}=1999, \ldots 2010$

In model 4, we test the institutional theory on productivity.

E4:

$$
\begin{array}{rl}
L P_{i t}=\alpha_{i}+\beta 1 & O F D I_{i t}+\beta 2 O F D I_{i t} * D C_{i t}+\beta 3 O F D I_{i t} \\
& * E E_{i t}+\beta 4 O F D I_{i t} * O A_{i t}+\beta 5 O F D I_{i t} \\
& * M D_{i t}+\beta 6 S T D_{i t}+\beta 7 D S O_{i t} \\
& +\beta 8 D F O_{i t}+\beta 9 A G E_{i t}+\beta 10 S I Z E_{i t} \\
& +\beta 11 K L_{i t}+\varepsilon_{i t}
\end{array}
$$

Where $\mathrm{i}=1, \ldots \mathrm{n}$ (observations), $\mathrm{t}=1999, \ldots 2010$

In model 5, we test all factors on productivity.

E5:

$$
\begin{array}{rl}
L P_{i t}=\alpha_{i}+\beta 1 & O F D I_{i t}+\beta 2 O F D I_{i t} * D C_{i t}+\beta 3 O F D I_{i t} \\
& * E E_{i t}+\beta 4 O F D I_{i t} * O A_{i t}+\beta 5 O F D I_{i t} \\
& * M D_{i t}+\beta 6 H R_{i t}+\beta 7 O P C_{i t} \\
& +\beta 8 N O F_{i t}+\beta 9 M K S_{i t}+\beta 10 S T D_{i t} \\
& +\beta 11 D S O_{i t}+\beta 12 D F O_{i t}+\beta 13 A G E_{i t} \\
& +\beta 14 S I Z E_{i t}+\beta 15 K L_{i t}+\varepsilon_{i t}
\end{array}
$$

Where $\mathrm{i}=1, \ldots \mathrm{n}$ (observations), $\mathrm{t}=1999, \ldots 2010$ 
Table 2. Regression Results (dependent variable: LP)

\begin{tabular}{|c|c|c|c|c|c|}
\hline & Model 1 & Model 2 & Model 3 & Model 4 & Model 5 \\
\hline \multicolumn{6}{|l|}{ FDI Variables } \\
\hline H1a:OFDI & $-0.0024(0.0221)$ & $-0.0010(0.0117)$ & $\begin{array}{c}0.0793 * * * \\
(0.0150)\end{array}$ & $\begin{array}{l}-0.0050 \\
(0.0222)\end{array}$ & $\begin{array}{c}0.0729 * * * \\
(0.0121)\end{array}$ \\
\hline H1b:OFDI*DC & $-0.0021(0.0053)$ & $-0.0020(0.0028)$ & $-0.0044 *(0.0027)$ & $\begin{array}{l}-0.0002 \\
(0.0055)\end{array}$ & $-0.0035^{*}(0.0020)$ \\
\hline H1c:OFDI*EE & $\begin{array}{c}-0.0072 \\
(0.0060)\end{array}$ & $\begin{array}{c}0.0004 \\
(0.0028)\end{array}$ & $\begin{array}{l}-0.0022 \\
(0.0026)\end{array}$ & $\begin{array}{l}-0.0066 \\
(0.0059)\end{array}$ & $\begin{array}{c}-0.0016 \\
(0.0020)\end{array}$ \\
\hline H1d:OFDI*OA & $\begin{array}{c}0.0091 \\
(0.0070)\end{array}$ & $\begin{array}{c}0.0030 \\
(0.0037)\end{array}$ & $\begin{array}{c}-0.0013 \\
(0.0033) \\
\end{array}$ & $\begin{array}{c}0.0105 \\
(0.0072)\end{array}$ & $\begin{array}{c}-0.0024 \\
(0.0026)\end{array}$ \\
\hline H1e:OFDI*MD & $0.0056(0.0278)$ & $0.0042(0.0141)$ & $\begin{array}{c}-0.0835 * * * \\
(0.0140) \\
\end{array}$ & $0.0070(0.0277)$ & $\begin{array}{c}-0.0692 * * * \\
(0.0111) \\
\end{array}$ \\
\hline \multicolumn{6}{|l|}{$\begin{array}{c}\text { Resource-based } \\
\text { Variables }\end{array}$} \\
\hline H2a: HR & & $\begin{array}{c}0.0400 * * * \\
(0.0193)\end{array}$ & & & $\begin{array}{c}0.0110 * * * \\
(0.0111)\end{array}$ \\
\hline H2b:OPC & & $\begin{array}{c}0.8005^{* * *} \\
(0.0163)\end{array}$ & & & $\begin{array}{c}0.1855 * * * \\
(0.0176)\end{array}$ \\
\hline \multicolumn{6}{|c|}{ Industry-based Variables } \\
\hline H3a: NOF & & & $\begin{array}{c}0.1727 * * * \\
(0.0121)\end{array}$ & & $\begin{array}{c}0.1519 * * * \\
(0.0105)\end{array}$ \\
\hline H3b:MKS & & & $\begin{array}{c}0.8789 * * * \\
(0.0181)\end{array}$ & & $\begin{array}{c}0.7644 * * * \\
(0.0201)\end{array}$ \\
\hline \multicolumn{6}{|l|}{$\begin{array}{c}\text { Institution-based } \\
\text { Variables }\end{array}$} \\
\hline H4a:STD & & & & $\begin{array}{l}-0.0859 \\
(0.0616)\end{array}$ & $\begin{array}{c}0.0044 \\
(0.0275) \\
\end{array}$ \\
\hline H4b:DSO & & & & $\begin{array}{c}-0.0880^{* *} \\
(0.0396)\end{array}$ & $\begin{array}{l}0.0207 \\
(0.0161)\end{array}$ \\
\hline H4c:DFO & & & & $\begin{array}{l}-0.0313 \\
(0.0707)\end{array}$ & $\begin{array}{c}0.0109 \\
(0.0240)\end{array}$ \\
\hline \multicolumn{6}{|l|}{ Control Variables } \\
\hline AGE & $\begin{array}{c}-0.0004 \\
(0.0026)\end{array}$ & $-0.0006(0.0008)$ & $\begin{array}{c}-0.0005 \\
(0.0010)\end{array}$ & $\begin{array}{c}-0.0005 \\
(15.956)\end{array}$ & $\begin{array}{c}-0.0002 \\
(0.0007)\end{array}$ \\
\hline SIZE & $\begin{array}{c}-0.5779 * * * \\
(0.04479)\end{array}$ & $\begin{array}{c}-0.7730 * * * \\
(0.0241) \\
\end{array}$ & $\begin{array}{c}-0.8763 * * * \\
(0.0214) \\
\end{array}$ & $\begin{array}{c}-0.5742 * * * \\
(0.0444)\end{array}$ & $\begin{array}{c}-0.8780 * * * \\
(0.0180) \\
\end{array}$ \\
\hline $\mathrm{KL}$ & $\begin{array}{c}0.2225 * * * \\
(0.0354)\end{array}$ & $\begin{array}{c}0.1207 * * * \\
(0.0312)\end{array}$ & $\begin{array}{c}0.0414^{* *} \\
(0.0175) \\
\end{array}$ & $\begin{array}{c}0.2207 * * * \\
(0.0355)\end{array}$ & $\begin{array}{c}0.0552 * * * \\
(0.0139)\end{array}$ \\
\hline $\operatorname{AR}(1)$ & Significant & & Significant & Significant & Significant \\
\hline F-statistic & $86.9043^{* * *}$ & $242.8270^{* * *}$ & $13.17195^{* * *}$ & $86.20855^{* * *}$ & $25.95214 * * *$ \\
\hline $\mathrm{N}$ & 859 & 1002 & 562 & 859 & 528 \\
\hline Ad. $\mathrm{R}^{2}$ & 0.8510 & 0.8716 & 0.7005 & 0.8518 & 0.8928 \\
\hline DW stat. & 2.1452 & 1.7069 & 2.5266 & 2.1548 & 2.0884 \\
\hline
\end{tabular}

Note: $* * *=\mathrm{P}<.01, * *=\mathrm{P}<.05,{ }^{*}=\mathrm{P}<.1$

\section{Results}

Hierarchical Fixed Effects regression analyses were used to test Hypotheses 1-4. Table 2 presents the regression results. Model 1, which only includes control variables and Hypothesis 1 variables (i.e., OFDI, Locations Dummy, Industries Dummy), serves as the baseline model of the study. Models 2-4 contain three additional groups of variables separately (i.e., resource-based variables, industry competition factors, and institution-based variables). We integrate all these variables simultaneously in Model 5. First, hypothesis 1 posits that OFDI with location and industry factors is positively related to productivity. Model 1,2 , and 4 show that OFDI with location and industry factors is not statistical significant, while in models 3 and 5, OFDI, OFDI, which located in developed country (DC), and OFDI firms in the manufacturing industry are highly significant. Thus, we think that OFDI factors significantly influence productivity in the home country when only we consider putting the industry competition factors into our model. We can conclude that the result partially supports Hypothesis 1 (a), (b), and (c). Also, the OFDI in emerging economies (EE) and other areas (OA) produce a statistically insignificant effect; this result does not support Hypotheses 1(c). Second, hypothesis 2 posits that human resource (a) positively related to productivity, but operating costs, (b) negative related to it. Therefore, we 
find that the result highly significantly supports hypothesis 2 (a), but it does not support hypothesis 2 (b) in models 2 and 5. Third, hypothesis 3 posits that industrial competition conditions (i.e., number of firms and market share) have a positive relationship to the productivity. From this result, both Models 3 and 5 shows that two variables associated with the number of firms and market share are statistically significant, corroborating hypothesis 3. Four, hypothesis 4 posits institutional factors (i.e., government policy, state ownership, and foreign ownership) are positively related to productivity in the home country. However, in model 4, state ownership does not support our hypothesis 4 . They have a significant negative relationship in model 4 , but insignificantly in model 5. Then, government policy and foreign ownership factors are significant in both models 4 and 5 . They both do not support hypothesis 4 .

\section{Conclusions}

From previous researches, they might consider only one aspect to check the factor which influenced productivity in domestic firms. We focus on the Chinese OFDI firms to inspect the determinants of increasing productivity in the home country. It is important because the home country's productivity effect of OFDI has acknowledged still little concentration in the empirical literature (Hsu et al., 2011). This research integrates three different aspects, but academic explanations to view the home country productivity effect of OFDI. In our findings, they show that the integrating model of three aspects has higher explanation than the individual aspect model. We use firm-level data to explain how the firm-specific factors, industrial factors, and national institution factors affect productivity in Chinese OFDI firms. Also, this analysis of firm-level data can provide evidences in the effectiveness of resource using, competitiveness, and policy impact on individual firms. Thus, we try to conclude some significant implications from our empirical results and giving some advice for the firms and policymakers.

First, OFDI factors positively influence home country productivity when we consider adding industrial factors to our models. That means the intensity of the home country productivity effect of OFDI is related to its industrial conditions such as competitive rivalry, entry barrier, and threat of substitutes. This may imply that when firms want to invest in a foreign country in order to boost their home country productivity, it has to focus on its position and to pursue high competition in the industry. The policymaker should create a well-completed environment for the industry, encouraging more firms to enter the industry with the purpose of making sure a healthy or constructive competition. Through strong competition in the industry, the performance of firms is improving, which is shown on the increasing productivity (Nickel, 1996).
Second, location factors in OFDI are still essentials to influence the productivity in the home country. We can observe that OFDI areas of Chinese firms are concentrating on specific locations. The government of China encourages firms to invest in the foreign countries which have specific advantages in biotechnology, computer science, and precision instruments industry by launching the Guide of Foreign Investment. With the development of globalization, Chinese firms want to seek strategic resources. Usually, we might think that investing in a developed country could absorb the advanced knowledge for increasing the home country's productivity, but from our result, it has a negative relationship to productivity. There are many possible reasons for investment in developed countries reduces home country productivity, like the gap of technology employed and management skills.

Third, resource-based theories explained a firm which owned a specific advantage to other competitors has a good performance in productivity. According to previous researches (Black \& Lynch, 1996; Fleisher et al., 2011; Hart, 1995; Christmann, 2000), we set the quality of education and total operating costs as two specific firm-owned indicators to resource-based factors to influence home country productivity. Our results show that higher education and operating costs can create higher productivity. On the one hand, education is the key to boost productivity in logical thinking. However, more operating costs probably represent that an MNE puts much larger capital than those of domestic firms in order to achieve scale economies (Caves, 1974). For a firm and policymaker, increasing the education quality of employees is a good way to boost the productivity. Black \& Lynch (1996) also point out training and recruit policy can affect boosting productivity.

Fourth, as we have discussed above, industrial conditions are critical factors to affect home country productivity. Chinese OFDI Firms should understand and gain relative knowledge in competition when they are involved in a global environment to taking more market share. The policymaker should be fairness and openness to the firms in industries. In order to ensure the firms' productivity is boosting can be benefited by industrial policy, the reward of being healthy competition must be clear. Otherwise, cut-throat competition is bad for industrial development.

Fifth, national institutional theories may not be the main reason to affect the home country productivity of OFDI firms from our results, but they are still useful to explain the relationship between the national policy and OFDI intensity (Wang et al., 2012). Many researchers found that state-owned enterprises (SOEs) have lower productivity than non-SOEs (e.g., Zhou. et al., 2002). Our model 4 supports this hypothesis. From the prior researches, they suggest that a firm should get along with the government, maintaining a good relationship. We think that it is reasonable because it may be helpful for long-term 
performance.

Sixth, the foreign stock-holding policy impact on home country productivity of Chinese OFDI firms is not significant in our empirical results. This policy impact probably revealed at domestic firms, not OFDI firms.

However, the OFDI firms and policymakers should concern the factors above, which affect boosting home country productivity when they evaluate future plans for sustainable development. The government should review how a future policy would disturb the productivity of SOEs.

Finally, the firm size and capital-labor ratio (KL) are all significant in the models. The same results were predicted by former researchers. The larger size of the firm has a low efficiency of the managerial system. Also, the more capitals for employees make productivity highly. Thus, we suggest the OFDI firms make downsize to the firm and try to promote lean manufacturing.

Although a surge in China's outward FDI might be economically sensible, the most active players have incentives to conduct excessive outward FDI, while capital constraints limit players that most likely have value-creating FDI opportunities. We then discuss plausible firm-level justifications for China's outward FDI, its importance, and promising avenues for further research.

\section{REFERENCES}

[1] Andersson, T. \& Fredriksson, T. 1996. "International organization of production and ariation in exports from affiliates.” Journal of International Business Studies, 27(2), 249-263.

[2] Aw, B. Y., Chung S. \& Roberts. M. J. 2000. "Productivity and Turnover in the Export Market: Micro-level Evidence from the Republic of Korea and Taiwan (China)." World Bank Economic Review, 14, 65-90.

[3] Bartelsman, E. J., Scarpetta, S., \& Schivardi, F. .2002. "Comparative analysis of firm demographics and survival: Micro-level evidence for the OECD countries.” Industrial and Corporate Change,14(3), 365-391.

[4] Benfratello, L. \& Sembenelli, A. .2006. "Foreign ownership and productivity: Is the direction of causality so obvious?" International Journal of Industrial Organization, 24. 733-751.

[5] Bitzer, J. \& Görg, H. . 2005. "The impact of FDI on industry performance.” International Trade Working Paper, 0505003, Econ WPA, Nottingham University, Nottingham.

[6] Black, S. E. \& Lynch, L. M. .1996. "Human-Capital Investments and Productivity.” The American Economic Review, 86(2), 263-267.

[7] Buckley, P. J., Clegg, J. L., Cross, A. R., Liu, X., Voss, H., \& Zheng, P. .2007. "The determinants of Chinese outward foreign direct investment.” Journal of International Business Studies, 38(4), 499-518.
[8] Buckley, P. J., Clegg, J. \& Wang, C. .2002. “The impact of inward FDI on the performance of Chinese manufacturing firms.” Journal of International Business Studies, 2002, 33(4), 637-655.

[9] Cantwell, J. .2002. "Innovation and technological competitiveness, Buckley P.J. \& Casson M. "Multinational Enterprises in the World Economy: Essays in Honour of John Dunning, 20-40. Aldershot, UK and Brookfield, USA: Edward Elgar.

[10] Caves, R. E..1974. "Multinational firms, competition and productivity in host country markets.” Economica, 41(162), 176-193.

[11] Christmann, P. 2002. "Effects of "best practices" of environmental management on cost advantage: The role of complementary assets.” Academy of Management Journal, 43, 663-680.

[12] Cui, J., \& Jiang, F. . 2010. "Behind ownership decision of Chinese outward FDI: Resource and institutions.” Asia Pacific Journal of Management, 27:751-774.

[13] Cuneo. P, Mairesse. J. .1983. "Productivity and R\&D at the Firm Level in French Manufacturing.” National Bureau of economic research, Working Paper No. 1068.

[14] Datta, D. K., Guthrie J. P. \& Wright P. M. .2005. "Human Resource Management and Labor Productivity: Does Industry Matter?.” The Academy of Management Journal, 48(1), 135-45.

[15] Denekamp, J. G. .1995. "Intangible Assets, Internalization and Foreign Direct Investment in Manufacturing.” Journal of International Business Studies, Vol. 26, No. 3, 493-504.

[16] Driffield, N., Love, J. H. \& Taylor, K. .2009. "Productivity and Labour Demand Effects of Inward and Outward Foreign Direct Investment on UK Industry." The Manchester School, 77(2), 171-203.

[17] Dunning, J. H. . Multinational enterprises and the global economy. 1993,Wokingham: Addison-Wesley.

[18] Dunning.J.H. .1998. "Location and the Multinational Enterprise: A Neglected Factor?.” Journal of International Business Studies, 29(1), 45-67.

[19] Dunning, J. H. . 2000. “The eclectic paradigm as an envelope for economic and business theories of MNE activity.” International Business Review,9, 163-190.

[20] Eaton, J., Kortum, S. \& Kramarz, F. .2004. "Dissecting Trade: Firms, Industries, and Export Destinations." American Economic Review, 94(1), 150-154.

[21] Fleisher, B. M. \& Chen, .1997. “The Coast-Noncoast Income Gap, Productivity, and Regional Economic Policy in China." Journal of Comparative Economics, 25(2), 220-236.

[22] Fosfuri, A., Motta, M. \& Rønde, T. .2001. "Foreign Direct Investment and Spillovers through Workers Mobility. “Journal of International Economics, 53(1), 205-222.

[23] Görg, H. \& Greenaway, D. .2004. "Much Ado about Nothing? Do Domestic Firms Really Benefit from Foreign Direct Investment?.” The World Bank Research Observer, 19(2), 171-197. 
[24] Guellec, D. \& Van Pottelsberghe de la Potterie, B. .2004. "From R\&D to Productivity Growth: Do the Institutional Settings and the Source of Funds of R\&D Matter?" Oxford Bulletin of Economics and Statistics, 66(3), 353-378.

[25] Hart, S. L. .1995. "A natural-resource-based view of the firm.” Academy of Management Review, 20, 874-907.

[26] Haskel, J. E., Pereira, S. C., \& Slaughter, M. J. .2002. "Does Inward Foreign Direct Investment Boost the Productivity of Domestic Firms?.” NBER Working Paper, 8724.

[27] Hausman, J. A. .1978. "pecification tests in econometrics." JA Hausman - Econometrica, Journal of the econometric society, 46(6):1251-1272

[28] Head, K. \& Ries, J. .2003. "Heterogeneity and the FDI versus export decision of Japanese manufacturers." Journal of Japanese International Economics, 17(4), 448-467.

[29] Hsu, W., Gao, X., Zhang, J. \& Lin, H. . 2011. "The effects of outward FDI on home-country productivity. Do location of investment and market orientation matter?.” Journal of Chinese Economic and Foreign Trade Studies, 4(2), 99-116.

[30] Johanson, J., \& Vahlne, J. E. .1997. "The internationalization process of the firm: A model of knowledge development and increasing foreign market commitments.” Journal of International Business Studies, $8(1), 23-32$.

[31] Kaufmann, L. .1997. “A Model of Spillovers trough Labor Recruitment.” International Economic Journal, 11(2), 13-34.

[32] Klassen, R. D., \& Whybark, D. C. .1999. “The impact of environmental technologies on manufacturing performance. “Academy of Management Journal,42, 599-615.

[33] Li, S. .1998. "Success in China's industrial market: An institutional and environmental approach.” Journal of International Marketing, 6(1), 56-80.

[34] Lieberman, M, B \& Kang, J. .2008. "How to measure company productivity using value-added: A focus on Pohang Steel (POSCO)." Asia Pacific Journal of Management, 25:209-224.

[35] Liu, X., Siler, P., Wang, C. \& Wei, Y. .2000. "Productivity Spillovers from Foreign Direct Investment: Evidence from UK Industry Level Panel Data.” Journal of International Business Studies, 31(3), 407-425.

[36] Luo, Y., Xue, Q. \& Han, B. .2010. "How emerging market governments promote outward FDI: Experience from China.” Journal of World Business, 45(1), 68-79.

[37] Mahoney, J. T. \& Pandain Jr. .1992. “The resource-based view within the conversation of strategic management. “Strategic Management Journal, 13(5), 363-380.

[38] Mcguckin, R. H. \& Nguyen S. V. .1995. “On productivity and plant ownership change: new evidence from the LRD." Rand Journal of Economics, 26(2), 257-276.

[39] Melitz, M. .2003. "The Impact of Trade on Intra-industry Reallocations and Aggregate Industry Productivity." Econometrica, 71(6), 695-725.
[40] Montagna, C. .2001. "Efficiency Gaps, Love for Variety and International Trade.” Economica, 68(1), 27-44.

[41] Nickel, S. J. .1996. “Competition and Corporate Performance. "Journal of Political Economy, 104(4), 724-746.

[42] Nigel Driffield, \& James.H, .2007. "Linking FDI Motivation and Host Economy Productivity Effects: Conceptual and Empirical Analysis." Journal of International Business Studies, 38 (3), 460-73.

[43] Pilat, D. .1996. "Competition, productivity and efficiency." OECD Economic Studies, 27, 107-146.

[44] Porter, M. . The competitive advantage of nations, New York: Free Press.

[45] Roeger, W. .1985. "Can Imperfect Competition Explain the Difference between Primal and Dual Productivity Measures? Estimates for U.S. Manufacturing.” Journal of Political Economy 103(2), 316-30.

[46] Root.F, \& Ahmed.A. .1979. "Empirical determinants of manufacturing direct foreign investment in developing countries.” Econimic development and cultural change, 27, 751-767.

[47] Scarpetta, S., Hemmings, P., Tressel T. \& Woo J. .2002. "The Role of Policy and Institutions for Productivity and Firm Dynamics: Evidence from Micro and Industry Data." OECD Economics Department Working Paper, 329.

[48] Sharma, S., \& Vredenburg, H. .1998. "Proactive corporate environmental strategy and the development of competitively valuable organizational capabilities." Strategic Management Journal, 19, 729-753.

[49] Sjöhölm, F. .1998. "Productivity Growth in Indonesia:The Role of Regional Characteristics and Direct Foreign Investment.” Working Paper in Economics and Finance, 216.

[50] Sun, S .2012. "The role of FDI in domestic exporting: Evidence from China”, Journal of Asian Economics, 23, 434-441.

[51] Wang, C., Clegg, J. \& Kafouros, M. .2009. "Country-of-origin effects of foreign direct investment: An industry level analysis.” Management International Review, 49(2), 179-198.

[52] Wang, C., Hong, J., Kafouros, M., \& Boateng, A. .2012. "What drives outward FDI of Chinese firms? Testing the explanatory power of three theoretical frameworks." International Business Review, 21, 425-438.

[53] Wang, J. Y., \& Blomstrom, M. .1992. "Foreign Investment and Technology Transfer: A Simple Model.” European Economic Review, 36(1), 137-155.

[54] Warner, M., Hong, N. S., \& Xu, X. .2004. "Late development experience and the evolution of transnational firms in the People's Republic of China.” Asia Pacific Business Review, 10(3-4), 324-345.

[55] Wei, Y. \& Liu, X. .2006. "Productivity Spillovers from R\&D, Exports and FDI in China's Manufacturing Sector." Journal of International Business Studies,37(4), 544-557.

[56] Wei Zhao, L. L. .2010. “The contribution of outward direct 
investment to productivity changes within China, 19912007.” Journal of International Management, 16, 121130.

[57] Wernerfelt, B. .1984. "A resource-based view of the firm. "Strategic Management Journal, 5, 171-180.

[58] Wright, P. M., McMahan, G. C., \& McWilliams, A..1991. "Human resources and sustained competitive advantage: a resource-based perspective." International Journal of Human Resource Management, 5(2), 301-326.

[59] Xu, B. .2002. "Multinational enterprises, technology diffusion, and host country productivity growth.” Journal of Development Economics, 62, 477-493.

[60] Zhang, A., Zhang, Y., \& Zhao, R. .2001. "Impact of Ownership and Competition on the Productivity of Chinese Enterprises.” Journal of Comparative Economics, 29, 327-346.

[61] Zhou, D., Li., S., \& Tse, D. K. .2002. "The impact of FDI on the productivity of domestic firms the case of China." International Business Review, 11, 465-484. 